\title{
Spinoza and Jewish Averroism:(*) The Textual Evidence
}

\author{
Dr. Ashraf Hassan Mansour \\ Professor, Faculty of \\ Arts, University of \\ Alexandria, Egypt
}

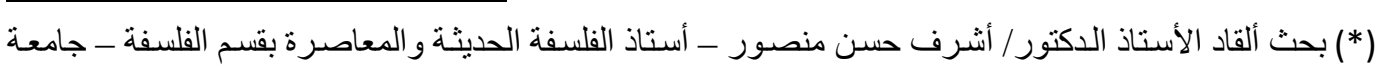

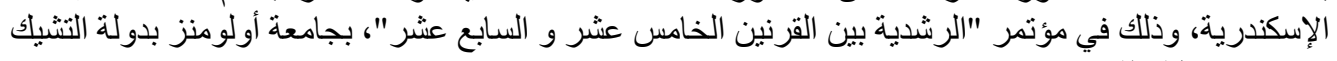




\section{Abstract:}

Several scholars have pointed out the impact of Jewish Philosophy on Spinoza (1632 - 1677), and the role of Jewish intellectual history from the late middle ages to the Renaissance in shaping his philosophy, but the influence of Jewish Averroism on Spinoza is still debatable and was continuously contested. In this article I will concentrate on the presence of some of the Jewish opponents and proponents of Averroism in the works of Spinoza, namely: Jehuda Al-Fakhar (early thirteenth century, d.1235), Levi ben Gershom (1288- 1344), Hasdai Crescas (1340 - 1411), and Joseph ibn Shem Tob $(1400-1460)$. These are the Jewish thinkers that were mentioned by Spinoza in polemical contexts, refusing the positions of Al-Fakhar and Joseph ibn Shem Tob concerning the subordination of Reason to Scripture and the subordination of rational morality to scriptural precepts respectively, defending the opposite position that was identical to Averroes'; and on the other hand accepting some of the ideas of Ben Gershom and Crescas that were identical with Averroes like the concept of circular infinity in Crescas that was a restatement of Averroes', and the eternity of matter in Ben Gershom that was his compromising Averroes' eternity of the world with creationism.

The aim of my investigation is to prove that Spinoza was well informed of Averroes' system from those philosophers, and he even put himself in the middle of the Jewish anti-Averroean debates, taking sides with the opposite positions of the Jewish opponents of Averroism. Spinoza, openly or tacitly, refused all the counter arguments of Al-Fakhar, Crescas and ibn Shem Tob against Averroes, and thereby adopting the Averroean positions that they attacked, without mentioning Averroes himself. This silence of Spinoza to the name of Averroes among all his writings while refusing the arguments 
of Averroes' Jewish opponents makes Spinoza's final position tacitly Averroean, so we can say that there is an Averroean subtext in the works of Spinoza that we can reveal by analyzing his dealings with Jewish anti-Averroism. 


\section{Introduction:}

Spinoza never mentioned Averroes by name in all of his writings, but this does not mean that he never knew Averroes' system, nor that there was no Averroean influence on him. I suggest in this article that Spinoza knew very well Averroes' philosophy in detail, via his wide reading of the opponents and proponents of Averroism among Jewish philosophers. Licata and Fraenkel pointed out the impact of the Renaissance Averroist Elijah de Medigo on Spinoza, who kept a copy of his book "Behinat Ha-dat/ Examination of Religion" in his library ${ }^{(1)}$; that work was a restatement of Averroes' Fasl Al Maqal, and its impact in Spinoza's differentiation between Philosophical Demonstrative discourse and Religious discourse is present in Spinoza's Tractatus Theologico Philosophicus. It is remarkable that Spinoza never mentioned any strict Jewish Averroist like Moses Narboni or Del Medigo himself, and that all those he mentioned were the opponents of Averroism: Jehuda Al-Fakhar (early thirteenth century), Levi ben Gershom (1288- 1344), Hasdai Crescas (1340 1411), and Joseph ibn Shem Tob (1400 - 1460).

\section{Al Fakhar's Opposition to the Philosophical (Averroist) Interpretation of Scripture:}

In one of his central chapters of the Tractatus, Spinoza enters in a hot debate with the thirteenth century Toledian Rabbi, Jehuda AlFakhar, opposing sharply his method of interpreting Scripture literally, that subordinates Reason to the literal meaning of the Bible. Spinoza discusses Al-Fakhar's method in the context of exposing two methods of interpreting Scripture: the first one subordinating Scripture to Reason, and the second on the contrary subordination Reason to Scripture. The first position is Maimonides' and the second one is Al-

1) Geffen, David M., Faith and Reason in Elijah Del Medigo's Behinat ha-dat and the Philosophic Background of the Work. PhD Dissertation, Columbia University, 1970. 
Fakhar's. We can assume confidently that those two positions were being held during the time of Spinoza, and that he did not enter into a discussion of a bygone trend in dealing with sacred texts; he is just mentioning the most well known representative of those two stances in Bible interpretation; that is why he notices immediately after mentioning Al-Fakhar's name that his position is the one adopted by the Rabbis. The debate between the literalists and the rationalists on Scriptural interpretation was still alive in Spinoza's time (Seventeenth century Netherlands). Notice that this debate was a continuation of the same debate that was first initiated in Islam between the Mu'tazillah and the Ashaarits, the Philosophers and the traditionalists.

Spinoza's discussion of Al Fakhar came after presenting his position toward the relation between reason and theology. In this context, Spinoza declares that the very question on the priority of one to the other is not a proper question, and that it was being asked by those who cannot differentiate between philosophy and theology. And what makes philosophy and theology not in conflict, is that Scripture is being adapted to the understanding of the common people, and in this regard we (the philosophers) must understand it; so that any interpretation of Scripture that puts meaning and intentions into it, not in line with the multitude, is not legitimate, because it deals with Scripture as if it was a book for the philosophers, whereas it is especially meant for the common people. It is on the basis of this differentiation between philosophy and theology that Spinoza discussed Al Fakhar's literal interpretation of Scripture, which accepted all that seems contradicting reason in it, on the basis of the infallibility of revelation and the subordinating of reason to it. This differentiation between philosophy and Scripture on the basis of the Scripture being written especially for the common people and that this is what makes it in no conflict at all with philosophy or reason, is the position Averroes took in his Fasl Al Maqal, where he said: "Now 
since this religion is true and summons to the study which leads to knowledge of the Truth, we the Muslim community know definitely that demonstrative study does not lead to [conclusions] conflicting with what Scripture has given us; for truth does not oppose truth but accords with it and bears witness to it". ${ }^{(1)}$

The aim of Spinoza in presenting those two positions of the relation between Reason and Scripture is to refute them both, and defending instead his own position, that "theology should not be subordinated to reason, nor reason to theology, but rather that each has its own domain. For reason, as we said, reigns over the domain of truth and wisdom, theology over that of piety and obedience" $(190)^{(2)}$. By refusing those two positions, Spinoza returned, implicitly, to the "Averroistic" position in Averroes' Fasl al Maqal, that is, the separation between reason and theology; and what made it an exclusively Averroistic position is that it was first initiated by Averroes himself, thereby differentiating himself from the previous positions of Al Farabi and Avicenna that attempted a reconciliation between reason and religion. It is well known now, after the studies by Fraenkl $^{(3)}$ and Licata ${ }^{(4)}$, that the Averroean position on the relation

1) Averroes, The Decisive Treatise, in Arthur Hyman, James J. Walsh \& Thomas Williams, Philosophy in the Middle Ages: The Christian, Islamic and Jewish Traditions 3rd ed. Indianapolis: Hackett, 2010, p. 292.

2) On the Averroistic origin, and the Averroistic understanding of the differentiation of the two domains, cf. Wolfson, Harry Austryn: "The Double Faith Theory in Clement, Saadia, Averroes and St. Thomas, and Its Origin in Aristotle and the Stoics", The Jewish Quarterly Review, New Series, Vol. 33, No. 2 (Oct., 1942), pp. 213-264.

3) Fraenkel, Carlos: "Could Spinoza Have Presented The Ethics as the True Content of the Bible?", in Daniel Garber and Steven Nadler (eds.), Oxford Studies in Early Modern Philosophy, 4, 2008; Fraenkel, Carlos: "Spinoza on Philosophy and Religion: The Averroistic Sources", in C. Fraenkel et.al. (eds), The Rationalists: Between Tradition and Innovation. (Springer, B.V. 2011), pp. 27-43; Fraenkel, Carlos: "Reconsidering the Case of Elijah Del Medigo's Averroism and its Impact on Spinoza", in Akasoy, Anna, \& Giglioni, Guido, Renaissance Averroism and its Aftermath: Arabic Philosophy in Early Modern Europe. (Dordrecht, Heidelberg, New York, London: Springer, 2013)

4) Licata, Giovanni, La via della ragione: Elia del Medigo e l'averroismo di Spinoza. Macerata: EUM, 2013. 
between reason and scripture was known by Spinoza from Elijah del Medigo's Behinat ha Da'at.

The question that poses itself upon us in this regard is: Did each position have any representatives in Spinoza's time? Yes, but not directly mentioned by Spinoza, and those were: Samuel da Silva (1570 - 1631) who wrote a refutation of Uriel da Costa's denial of the immortality of the soul, and Saul Levi Morteira (1596 - 1660) who was a member of the mahamad that excommunicated Spinoza in 1656 , both were on the side of the literal meaning of the Bible, subordinating thereby reason to Scripture, and Ludwig Meir on the side of subordinating Scripture to reason, especially Meir's "Philosophy the Interpreter of Scripture"(1).

It is obvious that Spinoza's position, differentiating the two realms, was unique in his lifetime, although it is the revival of del Medigo's Averroean position that was itself in line with previous positions by famous Jewish Averroists: Shem Tob ibn Falaquera (ct), and Moses Narbony. It is remarkable that Gersonides didn't belong to this strictly Averroean line, and perhaps this fact is behind Spinoza's refusal of his Bible interpretation, allegorizing Biblical stories, and that means a non Averroean stance towards those stories, by extending allegorical interpretation to a field never intentioned by the authors to be allegorical. But Spinoza is very respectful, even grateful, to Gersonides' philosophical writings ${ }^{(2)}$, that mentioned Averroes a lot. Mention the Hebrew translation of Fasl Al Maqal, its impact on Jewish Anerroism, besides the Latin's lack of knowledge of this book.

Al Fakhar was one of the first initiators of the so-called Maimonidean Controversy, opposing Maimonides' allegorical

1) Preus, J. Samuel, Spinoza and the Irrelevance of Biblical Authority. (Cambridge, New York: Cambridge University Press, 2001)

2) Spinoza, Theological - Political Treatise. Edited by Jonathan Israel, translated by Michael Silverthorne and Jonathan Israel. (Cambridge University Press, 2007), pp. $265-266$. 
interpretation of the Bible by defending its literal meaning ${ }^{(1)}$. Maimonides' method of a philosophical interpretation of the Bible was in conformity with Al Farabi, Avicenna, and Al Gazaly's interpretation of Quranic verses depending on Neo-platonism. This method intended to prove that the immanent meaning of Scripture is in conformity with Reason and a Rational system of the World, that is Neoplatonism. Spinoza refused this method of interpretation and regarded it as submitting Scripture to Reason. On the other hand, the Islamic philosophers' allegorical interpretation of the Quran was supposed to be esoteric, and that was mainly the position of Averroes. The fault of Maimonides was that in making this esoteric reading exoteric, despite his many warnings on the contrary. Maimonides transgressed Averroes' warnings that he himself repeated in his Guide, and that was what ignited the controversy.

\section{Spinoza's Critique of the Anti-Averroean Position of Joseph ibn Shem Tob on Rational Ethics}

Joseph ibn Shem Tob belonged to an age that witnessed the waning of Rationalism, and especially of Aristotelian-Averroean radical naturalism among the Jews, in comparison to the previous age (Thirteenth and Fourteenth centuries) that saw the flourishing of Jewish Averroism. That age began by the first confrontation to Averroism on purely philosophical grounds by Hasdai Crescas (1340 - 1410/11). Joseph's father, Shem Tob ibn Shem Tob, was one of the leading orthodox opponents of Averroism.

Joseph's Kevod Elohim (The Glory of God), the work Spinoza mentioned in his Tractatus, was the basis of his Commentary on Aristotle's Nicomachian Ethics that contained his critique of Averroes' middle commentary on the same work; in both works Joseph deals with religious morality that is opposed to an Aristotelian

1) Sarachek, Joseph, Faith and Reason: The Conflict Over The Rationalism of Maimonides. (New York: Hermon Press, 2nd ed. 1970), pp. 97 - 103. 
Philosophical system of ethics, defending the first against the second. The question that Joseph answers in both works was: Is a purely rational philosophical morality all that a virtuous man needs, or are religious precepts and rites indispensable? Joseph answered this question by announcing that in order to reach moral perfection, a would-be virtuous man needs religious morality, because it is his only means for salvation and for gaining a part in the world to come. Averroes and all Jewish Averroists insisted repeatedly that religious morality was suitable only for the multitude, that need religious guidance and a strict system of rituals and ceremonial laws to keep them in line by binding their desires, and that religion gives us only a minimum of ethics, whereas rational ethics, based on philosophical virtue and completely rational principles is the true means to moral perfection; the distinction between religious morality and rational ethics was based among the Averroists on a social distinction between the multitude and the philosophically educated elite (that was also the view of the Muslim Falasefa: Al Farabi, Avicenna, Avimpace, Aventofl, and had its echo in the Jewish Averroists: Al Balag ${ }^{(1)}$, Shem tob ibn Falaquera ${ }^{(2)}$, Moses Narboni ${ }^{(3)}$; the opposite view of Joseph had its predecessors in Hasdai Crescas and his critique of the Averroian theory of the rational perfection by the Acquired Intellect in his Or Adonai(4); Crescas was the first serious critic of Averroes on philosophical grounds, despite his borrowings from Al Gazzali.

1) Eliezer Schweid, The Classic Jewish Philosophers: From Saadia through the Renaissance. Translated by Leonard Levin. (Leiden \& Boston: Brill, 2008), pp. $320-$ 321.

2) Harvey, Steven, Falaquera's Epistle of the Debate: An Introduction to Jewish Philosophy. (Cambridge, Mass.: Harvard University Press, 1987).

3 ) Sirat, Colette, A History of Jewish Philosophy in the Middle Ages. (Cambridge: Cambridge University Press, 1985/1996), pp. 336 - 337.

4) Warren Harvey, Hasdai Crescas' Critique of the Theory of the Acquired Intellect. (PhD Dissertation, Columbia University, 1973) 
The true aim of Joseph's commentary on the Nicomachean Ethics was to confront Averroes' previous commentary on the same work. The opposition between rational ethics and religious morality was not an aim in Aristotle's work; it was Averroes, according to Joseph, who interpolated this opposition in his commentary. And that was what made Joseph turn to Aristotle's original text to re-interpret it to do away with Averroes' opposition ${ }^{(1)}$.

Joseph iben Shem Tob was in conformity with the orthodox view of his age that states that philosophy without the guidance of Scripture is dangerous to the Jews, because it constitutes a threat to the traditional belief in their religion. He even parts with some of the fiercest attackers of Averroism, blaming the spread of its heretical ideas among the Jews for Jewish unbelief, loss of faith among their multitude, and neutrality towards all religions that facilitated mass conversions to Christianity; Joseph in this regard made a commentary on Crescas' "Refutation of the Christian Principles", but surprisingly made use of some of Averroes' philosophical ideas on the unity of God to confront Christian Trinitarianism ${ }^{(2)}$.

Spinoza is remarkably harsh in criticizing Joseph ibn Shem Tob's denial of the sufficiency of rational ethics for salvation: "However, the Jews hold completely to the opposite view. They think that true opinions and a true conception of life make no contribution to happiness whenever people receive them by the natural light of reason alone and not as teachings prophetically revealed to Moses... Rabbi Joseph ben Shem Tov, in his book entitled Kevod Elohim, or Glory of

1) Meir Neria, Chaim, "It Cannot be Valued by the Gold of Ophir' (Job 28:16): Rabbi's Joseph b. Shem Tob's Commentary on Aristotle's Nicomachean Ethics. Sources and Analysis. (PhD dissertation: The Faculty of Divinity School, The University of Chicago, 2015), p. 6.

2) Hasdai Crescas, The Refutation of the Christian Principles. Translated with introduction and notes by Daniel S. Lasker. (Albany: State University of New York Press, 1992), pp. 42-43, 46, 52-54. 
God, adds that Aristotle (who he supposes has written the supreme Ethics, and whom he esteems above all others) missed nothing that was relevant to true morality and expounded it all in his Ethics and would have put it all conscientiously in to practice. Nevertheless, he adds, this would not have helped him towards salvation, since he did not receive these teachings as divine doctrine prophetically revealed, but derived them from the dictate of reason alone. I think it is evident to anyone who reads this attentively that all this is mere fabrication and does not rest upon the authority of the Bible, and hence one need only expound it in order to refute it ${ }^{\text {"(I) }}$.

Joseph ibn Shem Tob participated in the wide-held opinion among the rabbis of his age that pointed out the dangerous effect of philosophy, and especially Averroes', on Jewish faith, and he was in line with them in blaming Averroism for the mass conversion of the Jews to Christianity, based on a previous loss of faith in their original religion that facilitated their conversion to Christianity.

He put the responsibility on Averroean philosophy that made many Jews indifferent to all religions. His attack involved Moses Narboni's stance toward the Bible, that regards it as just a political book for the masses according to their own manner of thinking and imagining. Joseph rightly pointed out that this view of Narboni regarding the Bible was a restatement of the same opinion of Averroes regarding all sacred texts ${ }^{(2)}$. Joseph described this opinion as fallacious and heretical, based on a wrong conception of the Bible and its peculiar way to happiness and salvation.

Joseph's attack on the ethics of reason as the only true way to happiness and moral perfection was part of his overall strategy of confronting the influence of Averroes on the Jews in previous ages.

1) Spinoza, Theological-Political Treatise, p. 79.

2) Meir Neria, Chaim, "It Cannot be Valued by the Gold of Ophir", p. 18. 
The most important point in this regard is that Joseph didn't oppose Aristotelian ethics as such, because the Nicomachean Ethics never oppose the ethics of reason to religious ethics, and that this idea was Averroean, and it made its obvious appearance in Averroes' middle commentary on Aristotle's Nicomachean Ethics.

This is the reason why Joseph re-interpreted Aristotle's book: to show that the Averroean opposition between the ethics of reason and religious morality is not an issue in Aristotle's work, and that it was an interpolation by Averroes into that work by his commentary ${ }^{(1)}$. This was the principal aim of Joseph in his commentary.

\section{Spinoza on Maimonides' Position on the Eternity of the World:}

Maimonides refused to decide on the problem of the eternity of the world; his position was intentionally perplexing in spite of his book's title (Guide of the Perplexed); it is Maimonides' book that was perplexing to the uninitiated in philosophy, and that was one of his techniques in esotericism (Strauss et al, Spinoza's Critique of Religion). Spinoza didn't take Maimonides' Guide as an esoteric text, and took Maimonides' announced position literally on withholding the decision on the eternity of the world at face value, criticizing his exoteric position. So the conclusion that we can reach at this point is that Spinoza took the side of those philosophers that proclaim eternalism, and Averroes was among the leading of those philosophers. In his Ethics, Spinoza's system parts with eternalism, besides his early writings and especially in the text that he announced

1) Joseph is clear and straightforward in announcing that his intention in writing a commentary to Aristotle's work is confronting Averroes' previous commentary: “And while we have received from Averroes a topical commentary, without a literal commentary, in many cases the book is very far from Aristotle's intention, is not in agreement with his literal meaning, and in some cases, one could not understand a fitting intention without great labor and duress. And he omitted much of the value and learning of this book...", Ibid: p. 57. 
that he is in agreement with those ancient Hebrews who defended eternalism.

This is another textual evidence for Spinoza's parting with Jewish Averroism which defended eternalism: Al Balag, Falaquera, Moses Narbony, Elijah del Medigo.

It is likely that Spinoza knew eternalism, and even the eternal creation, via Uriel da Costa, who was influenced by Averroes or Jewish Averroism, according to some recent studies ${ }^{(1)}$, and previously by Rivera. Notice: Alcala de Hinares, a center for secret academic Averroism in Spain, that saw the presence of Joseph ben Shem Tob, da Costa, and maybe de Prado and some other important figures, Averroists and counter Averroists.

Spinoza blamed Maimonides for being indecisive on the issue of the eternity of the world. Maimonides announced clearly that he would accept eternalism if he could find a clear and straightforward proof of it in Aristotle, but he never found such a proof. At the same time, Maimonides' proof for the existence of God explicitly assumes the eternity of motion, and he even says that this is the only way for basing a proof capable of demonstrating God's existence. How then could he refuse eternalism in a certain part of his Guide, and announce clearly in another part that the eternal motion of heavens is the only way to prove the existence of God, the first mover? This indecision, that is really a kind of esotericism, is what made Spinoza criticize Maimonides in the Tractatus. The real opinion of Maimonides was eternalism, but this was his esoteric teaching, and he tried to hide it by using ways of esoteric techniques that he himself announced in his introduction. One way of hiding an opinion that was mentioned

1) Cf. Proietti, Omero: "Creazione eterna, ordine della natura, miracolo in Uriel da Costa », in Licata, Giovanni, Filippo Magnini, L'averroismo in eta moderna "1400 1700”. (Macerata: Qoudllibet, 2013), pp. $67-124$. 
clearly by him was by putting contradictory proofs to the same theory, another by announcing his refusal of an opinion, that is eternalism, and at the same time depending on that same view, that is the eternal motion of the spheres, in his central proof of the existence of God.

Eternalism was the opinion of Averroes, and he defended it explicitly in many of his works, not esoterically like Maimonides. But Maimonides had to be more cautious than Averroes and esoteric, and that was the reason behind his made-up reluctance on the issue of eternalism. This hesitation was not real, it was one of his techniques of hiding his true opinions. But this hesitation, even though it was an esoteric technique, was the object of Spinoza's criticism; Spinoza sticks to eternalism exoterically and clearly from early on, and that was obvious from his first works. In the final analysis, Spinoza's view of the relation between God and the world was clearly Averroean (see his refusal of the eternity of a prime matter that God imposed a form on it, and that was the theory of Gersonides and its origins go back to Plato), announcing that eternalism does not do any harm to religious faith (remember that this conclusion was the central aim of his Tractatus, so the misunderstood harm that is not really a harm for faith or civil peace is the eternity of the world, and that was exactly the opinion of Averroes, that was adopted by a number of Jewish philosophers: Al Balag (first but denying the theory after that), Falaquera, Narboni, Del Medigo. All those philosophers held the view that eternalism is not in conflict with religious piety, hence not a heresy.

\section{Spinoza's Adoption of the Averroean Concept of Circular Infinity via Hasdai Crescas}

When Spinoza mentioned Crescas in his $12^{\text {th }}$ letter to Meyer on the infinite, it was in the intention of using Crescas' theory of the possibility of the actual infinite as an aid to Spinoza's own theory. By 
the literal meaning of Spinoza's words, we cannot decide that Crescas was his main source for his own theory of the actual infinite, because it is obvious that Spinoza is just using Crescas as a previous historical example of a philosopher that admitted the actual infinite, and not the source for his own theory that he had proved independently from the beginning of the letter. The other source would be del Medigo's Averroist theory of the eternity of the world. This theory that appeared in its clear Averroist version in del Medigo, declares the possibility of the actual infinity of causes and effects, and the dependence of the sum-total of it on a first cause.

However, Crescas' main point is that the opposition of the philosophers between those who prove the existence of the first cause from the impossibility of a regression of causes ad infinitum, and those who prove it from the opposite assumption, is irrelevant, and that we may prove the existence of the first cause either way. And that means, according to Crescas' strategy in Or Adonai, that Reason cannot prove the existence of God, because even though each one of those theories is based on a true demonstration and thereby in a clear opposition towards the other, the existence of God is proved nevertheless, because his existence is naturally beyond Reason. That is the reason of his declaration "That there must exist a first cause, which is uncaused by anything else, regardless of the view whether its effects, when they are one the cause of the other, are infinite on finite $^{\text {,(1) }}$

And here Crescas defends an infinity of causes and effects and the dependence of the whole on a first cause (but he didn't mention the reason of their lack of a first cause even though there is an actual infinite mutual dependence among them that may make them

1) Wolfson, Harry A., Crescas' Critique of Aristotle. Problems of Aristotle's Physics in Jewish and Arabic Philosophy (Cambridge: Harvard University Press, 1929), p. 229. 
sufficient among themselves, and this is the problem that Averroes solved in his commentaries on Aristotle's Physics): “... it must be admitted that the emanation of an infinite number of effects from one single cause would not be impossible...". This idea is based on the omnipotence of God, i.e, that his power is infinite and is capable of producing infinite effects although it is just a single power. The idea of infinite effects from a single cause that is the power of God, an infinite cause himself (so that the infinite cause is the producer/ emanatory, of an infinity of effects) appeared in Averroes' Tahafut al Tahafut. In this idea of an infinite cause producing infinite effects we find the origin of Spinoza's same theory, and its origin is Averroes, via del Medigo, the only possible transmitter of this theory to Spinoza.

On the infinity of God's effects that is based on God's infinite power, Spinoza says: "From the necessity of the divine nature there must follow infinite things in infinite ways (modis)" (Ethics I, pr. 16). Spinoza then explains in the proof that this is based on the infinity of God's attributes. In the same direction, proposition 22 says: "Whatever follows from some attribute of God, insofar as the attribute is modified by a modification that exists necessarily and as infinite through that same attribute, must also exist both necessarily and as infinite". This proposition is based on the idea that an infinite cause could not produce finite effects, and that the infinity of God must necessarily produce infinite effects, otherwise it will contradict the essential nature of God. This idea also has its Averroean origin in the Tahafut, also in The Middle Commentary in De Caelo, although its main source is Proclus.

Crescas then posits his idea about an infinity of causes and effects, wherein the one effect is the cause of another effect that is a cause of another effect ad infinitum, and at the same time the dependence of all the causes and effects on one common cause, and 
that is exactly Averroes' idea about the infinity of change among the elements within the world (fire from air, air from water, water from earth, cf., Generation and Corruption), and also his idea of the dependence of an infinite circular motion on a first mover in Physics VIII). Crescas says: “... in as much as it is evident that there can be an infinite number of effects, despite there all being dependent upon a common cause, it must follow that the assumption of a common cause for more than one effect would not make it impossible for those effects to be infinite in number. This being the case, assuming now a series of causes and effects wherein the first is the cause of the second and the second of the third and so on for ever, would that I knew why, by the mere assumption of a common cause for the series as a whole, the number of causes and effects within that series could not be infinite? That their infinity is impossible on the ground of the dependence of the entire series upon a first cause is without any justification... no impossibility will happen if we assume those infinite effects to be each successively the cause of the other" ${ }^{\text {"(1) }}$. We must notice that all those possibilities of an actual infinite and an infinite series of causes and effects that all depends on a common cause is just a statement of mere possibility without any proof from Crescas; he posits it as a conceptual and theoretical possibility on the basis of the principle of non-contradiction (every statement that is not in contradiction to reason is possible), and that Averroes was the one who provided the proof. Notice also that this concept of an infinite that needs a first cause is not possible except as the concept of the circular infinite that Averroes proved that it is the only infinite conceivable, and that it is due to the infinite circular motion of the heavenly spheres. Crescas here put the Averroean theory of infinity dogmatically without its Averroean proof, and without its Physical Cosmological context; and that is exactly how the same theory

1) Wolfson, Crescas' Critique of Aristotle, pp. 225 - 227. 
appeared in Spinoza. It is remarkable that this same theory of circular infinity appeared in Hegel's Science of Logic ${ }^{(1)}$, where he said that the image of the true infinite is the circle, and in Cantor's set theory. Spinoza's infinity of Substance is exactly this circular kind of infinity, the holistic kind.

Melamed couldn't notice the similarity between Spinoza's and Crescas' position on the infinite, although this was the main purpose of his article. All that Melamed put his hand upon, is that Crescas and Spinoza agree on the circular relation between causes and effects ad infinitum, and at the same time the necessity of a first cause of this circular infinity, that is $\operatorname{God}^{(2)}$.

It is Averroes that demonstrated that the eternal circular motion of the spheres makes the world an infinite enclosed whole that its parts form a system of circular causality. This circular infinite causality among finite things is the idea that appeared in Spinoza's $28^{\text {th }}$ proposition in part I of Ethics, when he said: "Every individual thing, i.e., anything whatever which is finite and has a determinate existence, cannot exist or be determined to act unless it be determined to exist and to act by another cause which is also finite and has a determinate existence, and this cause again cannot exist or be determined to act unless it be determined to exist and to act by another cause which is also finite and has a determinate existence, and so ad infinitum". We can obviously trace the origin of this idea in Averroes' theory of the eternity of the world: the world is contingent in its parts, eternal in its whole (comm.. Meta, Lamm, comm. On generation and corruption).

1) Hegel, The Science of Logic. Translated and Edited by George di Giovanni (Cambridge: Cambridge University Press, 2010), pp. 108 - 121, especially 119. But notice that the circle is not just an image as Hegel said, nor is it not a metaphor, for it is actually the circular motion of the Sphere, a circle itself.

2) Melamed, Yitzhak Y.: "Hasdai Crescas and Spinoza on Actual Infinity and the Infinity of God's Attributes". Steven Nadler, Spinoza and Medieval Jewish Philosophy. (Cambridge University Press, 2014), pp. $204-215$. 
This circular infinity of the parts of the world as causes and effects to each other does not rule out the necessity of a first and final cause outside this whole, that is the cause of the circular infinity as such, that is, the eternal circular motion of the spheres, due to the eternal power of the first cause. Notice that this Averroean - Spinozan theory of an enclosed circular infinity in an enclosed, all-comprehensive whole, whether it is the universe in Averroes, or the Substance in Spinoza, reappears in Cantor's set theory, who read Spinoza, see Russell).

The copy of the Guide that was in Spinoza's library was printed with the commentaries of Shem Tob ben Joseph ben Shem Tob and Profiat Duran ${ }^{(1)}$. We cannot rule out all Averroean influences on those two commentaries, especially the first's, who differed from his family's traditional opposition to Averroes. Notice also that he had his own super-commentaries on Averroes.

In fact, Harry Wolfson tried to trace the presence of the ideas of Crescas and Gersonides in Spinoza's philosophy, but he forgot to notice that this presence means the implicit transference of Averroean ideas to Spinoza by those philosophers, that makes a kind of trace, not direct influence, and I borrow the concept "trace" from Althusser.

The most important idea in Crescas' theory of the actual infinite, is that this actual infinity between causes and effect do not rule out the dependence of the whole on a first cause; he expressed this idea in another way by his peculiar theory of the preponderance, the theory that we also find in Averroes, and in Spinoza. This preponderance that was mentioned by Crescas is not the Kalamic preponderance between the existence and the non-existence of a thing or of the whole world,

1) Freudenthal, Jacob, Die Lebensgeschichte Spinozas (Leibzig: Veit, 1899), p. 276, cited in Adler, Jacob: "Mortality of the soul from Alexander of Aphrodisias to Spinoza", in Steven Nadler, Spinoza and Medieval Jewish Philosophy, pp. 13 - 35, at 23. 
but it is the preponderance of the dependence against the nondependence of the infinite series of causes and effects on a first cause, that is, the eternity that needs a first cause against an eternity that is sufficient in itself ${ }^{(1)}$.

1) Warren Zev Harvey, Physics and Metaphysics in Hasdai Crescas. (Amsterdam: J.C. Gieben, 1998), p. 97. 


\section{Bibliography:}

- Averroes, The Decisive Treatise, in Arthur Hyman, James J. Walsh \& Thomas Williams, Philosophy in the Middle Ages: The Christian, Islamic and Jewish Traditions 3rd ed. Indianapolis: Hackett, 2010

- Crescas, Hasdai, The Refutation of the Christian Principles. Translated with introduction and notes by Daniel S. Lasker. (Albany: State University of New York Press, 1992)

- Fraenkel, Carlos: "Could Spinoza Have Presented The Ethics as the True Content of the Bible?", in Daniel Garber and Steven Nadler (eds.), Oxford Studies in Early Modern Philosophy, 4, 2008

- - --- "Reconsidering the Case of Elijah Del Medigo's Averroism and its Impact on Spinoza", in Akasoy, Anna, \& Giglioni, Guido, Renaissance Averroism and its Aftermath: Arabic Philosophy in Early Modern Europe. (Dordrecht, Heidelberg, New York, London: Springer, 2013)

- --------: "Spinoza on Philosophy and Religion: The Averroistic Sources", in C. Fraenkel et.al. (eds), The Rationalists: Between Tradition and Innovation. (Springer, B.V. 2011), pp. 27-43

- Geffen, David M., Faith and Reason in Elijah Del Medigo's Behinat ha-dat and the Philosophic Background of the Work. $\mathrm{PhD}$ Dissertation, Columbia University, 1970.

- Harvey, Steven, Falaquera's Epistle of the Debate: An Introduction to Jewish Philosophy. (Cambridge, Mass.: Harvard University Press, 1987).

- Hegel, The Science of Logic. Translated and Edited by George di Giovanni (Cambridge: Cambridge University Press, 2010) 
- Licata, Giovanni, La via della ragione: Elia del Medigo e l'averroismo di Spinoza. Macerata: EUM, 2013.

- Meir Neria, Chaim, "It Cannot be Valued by the Gold of Ophir' (Job 28:16): Rabbi's Joseph b. Shem Tob's Commentary on Aristotle's Nicomachean Ethics. Sources and Analysis. (PhD dissertation: The Faculty of Divinity School, The University of Chicago, 2015)

- Melamed, Yitzhak Y.: "Hasdai Crescas and Spinoza on Actual Infinity and the Infinity of God's Attributes". Steven Nadler, Spinoza and Medieval Jewish Philosophy. (Cambridge University Press, 2014)

- Preus, J. Samuel, Spinoza and the Irrelevance of Biblical Authority. (Cambridge, New York: Cambridge University Press, 2001)

- Proietti, Omero: "Creazione eterna, ordine della natura, miracolo in Uriel da Costa », in Licata, Giovanni, Filippo Magnini, L'averroismo in eta moderna "1400 - 1700". (Macerata: Qoudllibet, 2013)

- Sarachek, Joseph, Faith and Reason: The Conflict Over The Rationalism of Maimonides. (New York: Hermon Press, $2^{\text {nd }}$ ed. 1970)

- Schweid, Eliezer, The Classic Jewish Philosophers: From Saadia through the Renaissance. Translated by Leonard Levin. (Leiden \& Boston: Brill, 2008)

- Sirat, Colette, A History of Jewish Philosophy in the Middle Ages. (Cambridge: Cambridge University Press, 1985/1996)

- Spinoza, Theological - Political Treatise. Edited by Jonathan Israel, translated by Michael Silverthorne and Jonathan Israel. (Cambridge University Press, 2007) 
- Warren Harvey, Hasdai Crescas' Critique of the Theory of the Acquired Intellect. (PhD Dissertation, Columbia University, 1973)

- Wolfson, Harry A., Crescas' Critique of Aristotle. Problems of Aristotle's Physics in Jewish and Arabic Philosophy (Cambridge: Harvard University Press, 1929)

- Wolfson, Harry: "The Double Faith Theory in Clement, Saadia, Averroes and St. Thomas, and Its Origin in Aristotle and the Stoics", The Jewish Quarterly Review, New Series, Vol. 33, No. 2 (Oct., 1942), pp. 213-264. 